\title{
RELEVANT ISSUES OF SINGLE ETHICAL AND LEGAL SPACE CREATION ON THE TERRITORY OF TREATMENT AND PREVENTION INSTITUTIONS OF THE CRIMEAN FEDERAL DISTRICT
}

\author{
C Nataliya A. Ageeva \\ Rostov state medical university. Rostov-on-Don, Russian Federation \\ nataliya.ageeva@mail.ru
}

The article raises the questions of the necessity of medical activity bioethical measurement in the process of training and retraining of personnel for treatment and prophylactic institutions of the Crimean Federal District. In 2014 a resonant and long-awaited event took place - the annexation of the Crimea to the Russian Federation. From the very first days of the status change on the peninsula, the modernization of the health care system of the Republic of Crimea began by adapting it to modern Russian legislation. At the stage of transition, in difficult socio-political conditions, doctors were required the strict observance of the norms of international and Russian law. The author emphasizes that in the process of medical activity the doctor should be guided by the observance of ethical principles: justice, voluntariness, confidentiality and truthfulness. At the same time, according to the Federal Law "On the Fundamentals of the Protection of Citizens' Health in the Russian Federation" (Article 71), doctors promise to be merciful, highly moral, patient, in every way to protect the health of people, helping all without discrimination, keep a medical secret, to oppose euthanasia, to respect their teachers and colleagues, to improve their professional knowledge and skills. Article 20 of the above-mentioned Federal Law establishes the observance of the ethical principle of voluntariness, article 13 - confidentiality, article 22 - veracity. Observance of the principle of justice is dedicated to the Federal Law "On Compulsory Medical Insurance". Fulfilment of these principles with a doctor is a marker of a high level of his legal conscience and professional culture in general. The multinational and multireligious composition of the population in the Crimean Federal District points to the need for physicians to take into account the sociocultural and religious characteristics of patients. The author proceeds from the premise that high requirements to the level of training and retraining of personnel for the healthcare system of the Republic of Crimea can be realized on the condition that a single ethical and legal space is created in the territory of medical and preventive institutions of the Crimean Federal District.

Key words: bioethics, public health, Crimean federal district, modernization, legal consciousness, situational problems.

[Н.А. Агеева Актуальные вопросы создания единого этико-правового пространства на терри-
тории лечебно-профилактических учреждений Крымского федерального округа] Поднимаются вопросы необходимости биоэтического измерения медицинской деятельности в процессе подготовки и переподготовки кадров для лечебно-профилактических учреждений Крымского федерального округа. В 2014 г. состоялось резонансное и долгожданное событие - присоединение Крыма к Российской Федерации. С первых же дней изменения статуса на полуострове началась модернизация системы здравоохранения Республики Крым посредством ее адаптации к современному российскому законодательству. На этапе переходного периода, в сложных социально-политических условиях от врачей требовалось неукоснительное соблюдение норм международного и российского права. Подчеркивается, что в процессе медицинской деятельности врач должен руководствоваться соблюдением этических принципов: справедливости, добровольности, конфиденциальности и правдивости. Вместе с тем, в соответствии с Федеральном законом «Об основах охраны здоровья граждан в Российской Федерации» (ст. 71) врачи дают торжественную клятву, обещая быть милосердными, высокоморальными, терпеливыми, всячески охранять здоровье людей, помогая всем без исключения, не допуская дискриминации, хранить врачебную тайну, выступать против эвтаназии, уважать своих учителей и коллег, совершенствовать профессиональные знания и навыки. В статье 20 вышеуказанного Федерального закона закреплено соблюдение этического принципа добровольности, в статье 13 - конфиденциальности, в статье 22 - правдивости. Соблюдению принципа справедливости посвящен Федеральный закон «Об обязательном медицинском страховании». Соблюдение врачом этих принципов является маркером высокого уровня его правосознания и профессиональной культуры в целом. Многонациональный и многоконфессиональный состав населения в Крымском феде- 
ральном округе указывает на необходимость учета врачами социокультурных и религиозных особенностей пациентов. Автор исходит из того, что высокие требования к уровню подготовки и переподготовки кадров для системы здравоохранения Республики Крым могут быть реализованы при условии создания единого этико-правового пространства на территории лечебно-профилактических учреждений Крымского фредерального округа.

Ключевые слова: биоэтика, здравоохранение, Крымский федеральный округ, модернизация, правосознание, ситуационные задачи.

Nataliya A. Ageeva - candidate of philosophy, associate professor. Rostov state medical university. Rostovon-Don, Russian Federation.

Агеева Наталия Алексеевна - кандидат философрских наук, доцент. Ростовский государственный медицинский университет. г. Ростов-на-Дону, Россия.

Modernization of the Crimea Republic healthcare system began in 2014 - from the first days of the peninsula status. The process of the Crimea joining to the Russian Federation meant the need to adapt all systems of society's life to the requirements of modern Russian legislation. In difficult socio-political conditions, the medical community had to quickly integrate into a single ethical-legal space of the Russian health system. For the adaptation process effectiveness from October 14 to October 29, 2014, within the framework of the federal statistical observation "Population Census in the Crimean Federal District" with a $100 \%$ coverage of the population by order of the Government of the Russian Federation of July 17, 2014 No 1330 and order of Federal State Statistics Service from 01.08.2014 No 497 the population reckoning and obtaining of demographic, economic and social people characteristics, living in the Crimea Republic and Sevastopol were realized.

During the population census in 2014, all people living on the territory of the Crimean Federal District (CFD), were taken into account, irrespectively of citizenship and including temporarily absent. According to the census, 2,293,700 people were taken into account, from them the permanent population of the Crimean Federal District composes 2,284,800 people. At the same time people, temporarily staying at the territory of CFD, constantly living outside the Russian Federation were considered $-8,9$ thous. of people. The national population composition of CFD in percentage ratio: Belarusians - 1.0\%, Armenians - 0.5 $\%$, other nationalities $-1.7 \%$ (Azerbaijanis, Uzbeks, Moldovans, Jews, Koreans, Greeks, Poles, Gypsies, Chuvashes, Bulgarians, Germans, Mordvins, Georgians, Tajiks, Mari, Karaites, Krymchaks). The main countries of migrants birth: Ukraine - 356 thousand of people, Uzbekistan - 162.6 thousand of people, Kazakhstan - 29.4 thousand of people, Belarus -22.2 thousand of people, Tajikistan -9.8 thousand of people, Azerbaijan - 7,3 thousand of people [7].

The census data speak for the multinational and multi-confessional composition of the Crimean Federal District population, which is of particular relevance in the course of resolving questions on the health system modernization. It is known that the effectiveness of therapeutic cooperation between a doctor and a patient largely depends on the level of the medical officer's sense of justice and his ability to build a communication strategy in relations with his colleagues and a person who applied for help to a medical and preventive institution. The legal norms, confirmed in international and Russian legislation, oblige the medical community to observe ethical principles (justice, voluntariness, confidentiality and truthfulness), to know and take into account the psychophysical, sex, age, sociocultural and religious characteristics of the patient [1-3]. It should be noted that without knowledge and consideration of these features it is impossible at an individual level to perform qualitatively the performance of medical duties by the medical worker, and at the 
group level - competent planning and conducting biomedical research in such a multinational and multi-confessional country as Russia.

In this case, the emphasis should be done on words - "know" and "take into account". To learn about the requirements of modern Russian legislation in the field of medicine and health can be through self-education or on the courses of professional training and advanced training for medical professionals. However, this is not enough. As, "know" is too little, you need to be ready to "comply" with ethical and legal norms. Only a doctor with a high level of legal awareness will take into account the cultural and religious characteristics of the patient in medical activities, since the word "take into account" - implies strict observance of the law requirements [4, p. 38].

The evolution of modern Russian legislation in the field of medicine and healthcare is based on the principle of respect for the autonomy of the individual as one of the fundamental values of a civilized way of life. Federal Law No. 323-FL from November 21, 2011, "On the Fundamentals of the Citizens' Health Protection in the Russian Federation" [8] included clauses stipulating the duty of medical workers to take into account the cultural and religious characteristics of the patient: providing medical care to the patient, taking into account his physical state and with observance of the cultural and religious traditions of the patient (art. 6, part 1, point 2); admission of clergyman to the patient, and if he is on treatment in a hospital - to provide conditions for the religious rites conduct, which are possible in a stationary environment, including the provision of a separate room, if this does not violate the internal order of the medical organization (Article 19 , part 5 point 11); by religious reasons, in the presence of a written statement of a spouse or close relative, and in the absence of other relatives or the legal representative of the deceased or with the will of the deceased himself, made during his life, a pathological anatomical dissection is not performed, except in some cases (Article 67, part 3); pathological anatomical dissection is performed with respect for a decent attitude to the body of the deceased person and maintaining the maximum of its anatomical shape (art. 67, part 8).

Article 13 establishes the principle of confidentiality - compliance the medical secrecy. Article 20 establishes the right to receive by a patient in full accessible form the information on the goals, methods of providing medical care, the risks associated with them, possible options for medical intervention, its consequences, and the expected results of medical care. Strict adherence by the doctor to this article contributes to the effectiveness of therapeutic cooperation and the result of the treatment itself. Article 22 fixes the patient's right to know the whole truth about his state of health, thereby imposes a ban on "holy lie" [8].

Federal laws, health and hygiene rules and standards, the RF Criminal Code, the Code of Professional Ethics of the RF doctor are easier to assimilate in the process of compiling and solving situational problems theoretically possible in medical activity. This should be taken into account during the training of personnel for the Russian health care system in general and medical workers in the Crimean Federal District - in particular. During the medical personnel training in the refresher courses, one can use methods of working with normative documents when drawing up and solving situational problems in violation of ethical principles: justice, voluntariness, confidentiality and truthfulness [5, p. 180]. For instance, several examples of situational problems in bioethics with standard answers:

Situational task No.1

On the operation eve, an anesthesiologist-resuscitator came to the patient in the department for conversation. At the end of the conversation, the doctor announced to the patient the amount of money ( 7 thousand rubles) that she had to pay him before the operation. He explained this by the need to pay 5 thousand rubles for his work and 2 thousand rubles to medical sisters. The woman said that she will not pay, because she can be treated free of charge in this institution - under the policy of obligatory medical insurance. The 
doctor answered her: "If you want to wake up after the operation, then forget about free medicine". The patient appealed to the head of the intensive care unit with a request to replace the doctor and to see into the situation with extortion of money. Explain, does the patient have the right to demand replacement of a doctor? Assess the validity of the anesthesiologist-resuscitator actions?

The standard response to ST No. 1

In this case, the ethical principle of justice is violated. The doctor's actions are illegal because, according to Article 19 (part 2) of the above Federal Law, each patient has the right to medical care in a guaranteed amount provided without payment in accordance with the program of state guarantees of free medical care to citizens. According to Article 27 of the RF doctor Code Professional Ethics: "When providing medical care, a doctor should remember that his profession is not a business. When organizing the treatment and diagnostic process, including the provision of medicines, the priority for the doctor is the provision of necessary and high-quality medical care, and not the extraction of commercial benefits for himself and the medical institution in which he works".

According to Article 19 (part 5, clause 1) of the Federal Law of 21.11.2011 No. 323FL "On the fundamentals of protecting the health of citizens in the Russian Federation", the patient has the right to choose a doctor and the choice of a medical organization. Consequently, the patient had the right to demand from the head of the structural unit to replace the doctor on the basis of the reasons stated in the written statement: extortion and threat to life.

In this case, the actions of an anesthesiologist-resuscitator doctor fall under Article 163 (part 1) of the Russian Federation Criminal Code. Extortion of money is carried out in a "simple composition", which implies punishment: restriction of freedom for up to four years, or forced labor for up to four years with restriction of freedom for up to two years, or without it, or arrest for up to six months, or deprivation freedom for up to four years with a fine of eighty thousand rubles or in the amount of the wage or other income of the convicted person for a period of up to six months, or without it. In the Decree of the Plenum of the RF Supreme Court "On Judicial Practice in Extortion Cases" No. 56 of December 17, 2015 , it is stated that the extortionist can act with the intent to obtain benefits for himself or for others (part 1). The threat to the victim must be perceived as real, as if the perpetrator can at any time realize it (part 6). If the victim did not comply with the demand of the extortioner, this does not affect the evaluation of the act. It will still be recognized as extortion.

Situational task No.2

After the tooth treatment, the dentist sent the patient to the registry to pay for the work. In the registry, the patient was given two documents for signing: 1) contract for the provision of paid medical services and 2) a sheet of informed voluntary consent for medical intervention. In this case, which part of the Federal Law of November 21, 2011, No. 323-Ф3 "On fundamentals of the RF citizens health protecting" was violated by a doctor?

The standard response to ST No. 2

In this situation, the ethical principle of voluntarism is violated, as in Article 20 of the Federal Law No. 323-Ф3 of November 21, 2011 "On the fundamentals of protecting the health of citizens in the Russian Federation" states: "The necessary precondition for medical intervention is the giving of informed voluntary consent of a citizen or his legal representative for medical intervention on the basis of the information provided by the medical officer in an accessible form about the purposes, methods of rendering medical assistance, related risk, options for medical intervention, its consequences, as well as the expected outcome of health care". The doctor was required to sign with the patient a sheet of informed voluntary consent before dental treatment, and not after medical intervention.

Situational task No.3 
The doctor at the district hospital became aware that one of his patients had a positive reaction to HIV infection. Being familiar with the friends of the patient, the doctor wanted to inform them about it. How, according to the Russian legislation, the doctor should act, having learned about a HIV-status of the patient?

The standard response to ST No. 3

In this case, the doctor's desire to tell his friends about the patient's HIV status could lead to a breach of the confidentiality ethical principle. According to Article 13 of the Federal Law "On Preventing the Spread in the RF of a Disease Caused by the Human Immunodeficiency Virus (HIV)", health facilities are required to: create conditions for the realization of the rights of HIV-infected persons provided for by law, including the right to privacy of personal information, but warn them of criminal liability for actions fraught with the risk of infection, or leading to the infection of another person. The doctor had to explain to the patient the main provisions of Article 122 of the Criminal Code: 1). Knowingly placing another person in danger of HIV contamination is punishable by restriction of freedom for up to three years, or by arrest for a period of three to six months, or by imprisonment for up to one year. 2). Infection of another person with HIV infection by a person who knew of his illness is punished with imprisonment for up to five years.

Situational task No. 4

The oncologist doctor performed a successful operation and after receiving the results of the histological analysis he diagnosed the patient with a nasopharyngeal cancer. His patient (a capable man of 37 years) decided not to upset and told about all his relatives, not having written permission from the patient. Whether actions of the doctor are lawful?

The standard response to ST No. 4

In this case, the ethical principle of truth is violated. The doctor's actions are illegal. The principle of "holy lie" was abolished in accordance with Article 22 (part 1, part 2, part 3 ) of the Federal Law from 21.11.2011 No. 323-Ф3 "On the fundamentals of the RF citizens health protecting":

1. Each patient has the right to obtain information about the state of his health in an accessible form, including information on the results of the medical examination, the presence of the disease, the established diagnosis and the prognosis of the disease development, the methods of medical care providing, the risk associated with them, possible types of medical intervention, its consequences and the results of medical care.

2. Information about the state of health is provided to the patient personally by the attending physician or other medical personnel directly involved in medical examination and treatment. In relation to persons who do not reach the age specified in subsection 54 (2) of this Federal Law and citizens recognized as legally incompetent, information on the state of health is provided to their legal representatives.

3. Information about the state of health can not be given to the patient against his will. In case of an unfavorable prognosis of the development of the disease, the information should be reported in a delicate form to the citizen or his spouse, one of the close relatives (children, parents, adopted children, adoptive parents, siblings, grandchildren, grandmothers) if the patient has not banned to inform them about it and (or) did not specify another person to whom such information should be transferred.

At the beginning of $X X$ century, VM. Bekhterev warned that "... ignorance and lack of education is the main condition for the individual underdevelopment" [6, p. 125]. The problems of spiritual and moral education, overcoming ignorance and adaptation of Russian and foreign medical students to the realities of modern life were raised in a number of published works [9-11]. The dynamics of the development of a modern innovative society sets a certain life standard, obliging medical workers to keep pace with the times and comply with the ethical and legal norms, worked out by the medical community. On the in- 
dividual level, the incompetence of the medical worker can be qualified as ignorance, and in the general cultural one - as the ideology of anti-humanism, which entails an increase in the number of "medical errors". The term "substandard service" is applicable to medical services that caused damage to the life or health of the patient. The entire medical community is called upon to be responsible for implementing and supporting legislative norms, aimed at meeting public health needs [2, p. 27].

Certainly, self-education and raising the level of one's professional culture is necessary not only for members of the medical community, but for all pedagogical workers, involved in training personnel for the Russian health care system. In the development of the students' personality medical mentality, much depends on the competence level of the teaching staff, on its ability to actualize, structure and visualize the educational material, from the positive tone of the dialogue, from a personal example of anti-corruption behavior.

In conclusion, one would like to emphasize that the creation of a single ethical-legal space in the territory of medical and preventive institutions of the Crimean Federal District is possible through the synchronization of the modernization of the education and health systems, during which the members of the medical community will pass from competence to competency, that is, from acquiring knowledge and skills before they are implemented in practice.

\section{Лumepamypa}

1. Агеева Н.А. Волонтерская деятельность как эфффективное средство социализации молодежи // Экономические и гуманитарные исследования регионов. 2015. № 1.

2. Агеева Н.А. Коррупция в системе здравоохранения РФ как уродливая форма правосознания индивидов // Гуманитарные и социальные науки. 2014. №1.

3. Агеева Н.А. Этико-правовой аспект невежества // Гуманитарные и социальные науки. 2014. № 2.

4. Агеева Н.А. Система менеджмента качества как эффрективная фрорма работы по сокращению количества дефектов оказания медицинской помощи в ЛПУ // Жизнь без опасностей. Здоровье. Профилактика. Долголетие. 2015. Т. 10. № 1.

5. Агеева Н.А. Социализация студентов-медиков: путь от компетенций к компетентности. Личность в меняющемся мире: здоровье, адаптация, развитие. 2017. т. 5. № 2 (17).

6. Бехтерев В.М. Проблемы развития и воспитания человека. М., 1997.

7. Итоги переписи населения 2014 года в Крымском фредеральном округе [Электронный ресурс] - Режим доступа:

http://www.gks.ru/free_doc/new_site/population/demo/perepis_krim/prez_surinov.pd $\mathrm{f}$ (дата обращения 02.05.2018).

8. Федеральный закон от 21 ноября 2011 г. № 323-Ф3 «Об основах охраны здоровья граждан в Российской Федерации» [Электронный ресурс] - Режим доступа: http://base.garant.ru/12191967/ (дата обращения 02.05.2018).

9. Шаповал Г.Н., Камалова О.Н. Оптимизация обучения иностранных студентов медицинских вузов в условиях культурной адаптации в рамках ФГОС третьего поколения // Гуманитарные и социальные науки. 2013. № 4.

10. Шаповал Г.Н. Поддержание высокого уровня мотивации обучения в ходе социализации личности иностранного студента медицинского вуза // Гуманитарные и социально-экономические науки. 2015. № 1 (80). 
11. Shapoval G.N. Foreign medical students adaptation in the conditions of humanization and humanitarization of higher education // Научный альманах стран Причерноморья. 2016.№ 1 (5).

\section{References}

1. Ageeva N.A. Volunteering activity as an effective means of youth socializing // Economic and humanitarian regions studies. 2015. No 1.

2. Ageeva N.A. Corruption in the health care system of the Russian Federation as an ugly form of the legal consciousness of individuals // Humanities and social sciences. 2014. №1.

3. Ageeva N.A. Ethical and legal aspect of ignorance // Humanities and social sciences. 2014. № 2.

4. Ageeva N.A. Quality management system as an effective form of work to reduce the number of defects in the provision of medical care in the medical and preventive treatment facility // Life without danger. Health. Precaution. Longevity. 2015. V. 10. No 1.

5. Ageeva N.A. Socialization of medical students: the path from competence to competency. Personality in a changing world: health, adaptation, development. 2017 . V. 5. No 2 (17).

6. Bekhterev V.M. Problems of human development and education. M., 1997.

7. Results of the 2014 Population Census in the Crimean Federal District [Electronic resource] - Access mode:

http://www.gks.ru/free_doc/new_site/population/demo/perepis_krim/prez_surinov.pd $f$ (date 02.05.2018).

8. Federal Law of November 21, 2011 No. 323-FZ "On the fundamentals of protecting the health of citizens in the Russian Federation" [Electronic resource] - Access mode: http://base.garant.ru/12191967/ (date 02.05.2018).

9. Shapoval G.N., Kamalova O.N. Optimization of foreign students medical schools training in conditions of cultural adaptation within the framework of FSES of the third generation // Humanitarian and socio-economic sciences. 2013. No 4.

10. Shapoval G.N. Maintaining a high level of motivation for training during the foreign student personality socialization of medical university // Humanitarian and socioeconomic sciences. 2015. No 1 (80).

11. Shapoval G.N. Foreign medical students adaptation in the conditions of humanization and humanitarization of higher education// Science almanac of Black sea region countries. 2016. No 1 (5). 